\title{
Effect of dietary fibre and condensed tannins concentration from various fibrous feedstuffs on in vitro gas production kinetics with rabbit faecal inoculum
}

\author{
K. Kara ${ }^{1}$ \\ Erciyes University, Faculty of Veterinary Medicine, Department of Animal Nutrition and Nutritional Diseases \\ 38280 Kayseri, Turkey
}

KEY WORDS: dietary fibre, tannins, fibrous feedstuffs, in vitro gas production, rabbit

Received: 9 March 2016

Revised: 1 June 2016

Accepted: 11 August 2016

${ }^{1}$ Corresponding author: e-mail: karakanber@hotmail.com; kanberkara@erciyes.edu.tr
ABSTRACT. The aim of the study was to compare nutrients, condensed tannins, fibre and in vitro fermentation parameters from different fibrous feedstuffs, both common (sugar beet pulp, wheat bran, lucerne meal) and uncommon (tomato pomace, maize bran, rice bran, lentil bran and pomegranate peel) in rabbit feeds with the in vitro gas production technique using rabbit faeces inoculum. The total dietary fibre and insoluble dietary fibre concentration were the lowest (28.9 and $23.7 \%$ ) for rice bran and the highest (70.2 and $63.1 \%)$ for sugar beet pulp. The highest digestible fibre fraction was in sugar beet pulp (44.5\%). The highest total condensed tannin, bound condensed tannin and extractable condensed tannin levels were determined in lentil bran. The in vitro gas production from insoluble fraction ( $b_{\text {gas }} ; 111$ and $100 \mathrm{ml} \cdot 0.5 \mathrm{~g}^{-1} \mathrm{DM}$, respectively) and potential gas production values $\left[(\mathrm{a}+\mathrm{b})_{\text {gas; }} ; 105.5\right.$ and $94.7 \mathrm{ml} \cdot 0.5 \mathrm{~g}^{-1} \mathrm{DM}$, respectively] were the highest in tomato pomace and sugar beet pulp. The $b_{\text {gas }}$ and $(a+b)_{\text {gas }}$ values of maize bran were higher by about $50 \%$ than those of wheat and rice bran $(P<0.001)$. The $b_{\text {gas }}$ and $(a+b)_{\text {gas }}$ values of pomegranate peel were approximately 4 times higher than those of lentil bran $(P<0.001)$. These results suggested that considering in vitro gas production tomato pomace, maize bran and rice bran could be further studied for use as alternative dietary fibrous feedstuffs for rabbit. It can be suggested that pomegranate pomace and lentil bran could be used as alternative dietary fibrous feedstuffs for the growing rabbit due to their high fibre content and low fermentation capacity.

\section{Introduction}

The rabbit is a monogastric herbivorous animal, and its digestive anatomy and physiology are well adapted to high intake of fibrous feedstuffs (Gidenne et al., 2010). The rabbit caecum, which constitutes $40 \%$ of the total digestive tract, is the main compartment for structural carbohydrates (fructans, galactans, mannans, mucilage, pectins, hemicelluloses, cellulose) degradation and fermentation processes. These fibrous substances of structural carbohydrates are important for the gut environment due to their influence on the digesta passage rate and mucosa functionality, and their role as a substrate for microbiota. The total dietary fibre in fibrous feedstuffs includes cell wall components [water-soluble non-starch polysaccharides (part of $\beta$-glucans, arabinoxylans, part of pectic substances) and water-insoluble poly- 
mers (lignin, cellulose, hemicelluloses and pectic substances)] and cytoplasm components (oligosaccharides, fructans, resistant starch and mannans) (Gidenne et al., 2010; Gidenne, 2015). Therefore, total dietary fibre (TDF) is the main constituent (up to $50 \%$ ) of a complete rabbit feed (Alvarez et al., 2007; Gidenne, 2015). TDF comprises insoluble and soluble substances. Soluble dietary fibre (SDF) consists of viscous soluble polysaccharides such as pectins, gums, $\beta$-glucans, mucilage, mannans, and a certain amount of resistance starch which has the capacity to bind water, thus forming a gelatinous mass in the small intestine. This mass slowly passes through the small intestine, modifying the efficiency of digestive enzymes. SDF substances are rapidly fermented in the large intestine (Gidenne, 2015), and can help to control pathogenic flora and to prevent digestive disorders (Alvarez et al., 2007). The main components of insoluble dietary fibre (IDF) are hemicelluloses (moderately digestible), cellulose (slowly digestible) and lignin (non-digestible) (Gidenne, 2015).

By-products of the agro-industry, such as cereal bran and fruit pulps, rich in soluble and digestible fibres, are dietary fibre feedstuffs commonly used in the complete rabbit feed. Nevertheless, particularly for their ability to prevent digestive problems, they should be present among the feed ingredients of rabbit complete feed (Gidenne, 2003). Sugar beet pulp and wheat bran are the most commonly used fibre feedstuffs for rabbit nutrition. Therefore, the digestion levels and nutrient compositions of other alternative dietary fibre feedstuffs need further examination.

In vivo digestibility experiments are expensive and time-consuming as they require lots of animals and large amounts of feed. The in vitro cumulative gas production technique was used to evaluate the nutritive value of feeds according to their fermentation kinetics (Kara, 2015; Kara et al., 2015). This technique has been applied successfully in different animal species, for example in ruminants (Kara, 2015; Kara et al., 2015; Miltko et al., 2015), horses (Elghandour et al., 2016), chickens (Guo et al., 2003) and rabbits (Bovera et al., 2010). Bovera et al. (2006) suggested that the faeces could be used as an alternative inoculum instead of caecal content for in vitro gas production techniques in rabbit. This study compared the fibre substances and in vitro fermentation parameters of different fibre feedstuffs (both common and uncommon) with the in vitro gas production technique using rabbit faeces inoculum.

\section{Material and methods}

\section{Substrate preparation}

As substrates were used 8 dietary fibre feedstuffs: 3 commonly used - sugar beep pulp, lucerne meal and wheat bran, and 5 non-commonly used tomato pomace, maize bran, rice bran, lentil bran and pomegranate peel.

Dried sugar beep pulp, lucerne meal, wheat bran, maize bran, rice bran and lentil bran were obtained from a feed processing factory (Kayseri Feed Factory) in Kayseri province (Turkey). Lucerne meal was at the early flowering stage (about $10 \%$ of flowering). Pomegranate peel was obtained fresh from the pomegranate juice production in a fruit juice factory (Meysu Food Industry and Trade) in Kayseri province (Turkey). Tomato pomace was obtained fresh from the tomato juice production factory in the Kayseri province (Turkey).

The samples of fresh and wet tomato pomace and pomegranate peel were dried in a thermostatically controlled cabinet (Lovidond; Dortmund, Germany) for $48 \mathrm{~h}$ at $55^{\circ} \mathrm{C}$. Dried tomato pomace, pomegranate peel and other fibrous samples were stored at $4{ }^{\circ} \mathrm{C}$ until chemical analyses and in vitro gas production.

\section{Chemical analyses}

The samples of all feedstuffs were milled through a $1 \mathrm{~mm}$ sieve (IKA MF10.1; Staufen im Breisgau, Germany) for chemical analyses and in vitro gas production. The analyses of concentrations of dry matter (DM), ash, crude protein (CP) and diethyl ether extract (EE) were conducted in accordance with the AOAC International (2012) methods: 934.01, 942.05, 954.01 and 920.39, respectively. The neutral detergent fibre (NDF), acid detergent fibre (ADF) and acid detergent lignin (ADL) contents of fibrous feedstuffs were determined in approximately $1 \mathrm{~g}$ samples with the use of a fibre analyser (Velp Scientifica FIWE3; Usmate, Italy) according to the methods given by Van Soest et al. (1991). The NDF was determined using $0.5 \mathrm{~g}$ sodium sulphite and $200 \mu 1$ thermo-stable $\alpha$-amylase (aNDF) (Megazyme; Wicklow, Ireland). Total aNDF, ADF and ADL contents were corrected for ash (aNDFom, ADFom and ADL, respectively). Analyses were carried out in duplicate.

Total dietary fibre (TDF), soluble dietary fibre (SDF) and insoluble dietary fibre (IDF) contents were determined according to the AOAC enzymaticgravimetric method (Prosky et al., 1988). The basis of this method constitutes the isolation of dietary 
fibre by enzymatic digestion of the rest of the feedstuff constituents. The residue was determined gravimetrically. Starch in the feedstuff (approximately $1 \mathrm{~g})$ was digested by mixture of amylase $(\mathrm{pH} 6.0$; temperature, $\mathrm{T}=100{ }^{\circ} \mathrm{C}$; time, $\mathrm{t}=30 \mathrm{~min}$ ) and

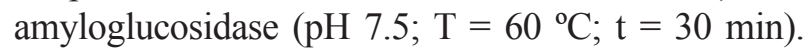
Protein in the feedstuff was digested with protease ( $\left.\mathrm{pH} 4.5 ; \mathrm{T}=60{ }^{\circ} \mathrm{C} ; \mathrm{t}=30 \mathrm{~min}\right)$. Ethanol $(95 \%)$ was added to precipitate the soluble fibre and the obtained sample was then incubated for $60 \mathrm{~min}$. Filtration was carried out in crucibles (Velp; Usmate, Italy) by using a filtration system (Velp Scientifica CSF 6; Usmate, Italy). Protein and ash were measured in each residue in order to correct the values for dietary fibre. Dietary fibre analyses were performed using Megazyme chemicals (Wicklow, Ireland) and were conducted in duplicate.

The total condensed tannin (TCT) content was determined using the butanol- $\mathrm{HCl}$ procedure of Makkar et al. (1995) at $100^{\circ} \mathrm{C}$ in the presence of $\mathrm{Fe}^{3+}$. Extractable condensed tannins (ECT) were extracted with acetone/water mixture at room temperature over $24 \mathrm{~h}$ and then in the same sample condensed tannins were determined (bound condensed tannins; $\mathrm{BCT}$ ) using the butanol- $\mathrm{HCl}$ procedure of Makkar et al. (1995) at $100{ }^{\circ} \mathrm{C}$ incubation in the presence of $\mathrm{Fe}^{3+}$. The ECT was calculated with an equation: $\mathrm{ECT}=\mathrm{TCT}-\mathrm{BCT}$. A bsorbance values were analysed using a spectrophotometer (UviLine 8100, SI Analytics; Mainz, Germany) at $550 \mathrm{~nm}$ wavelength. Measurements were performed in duplicate.

\section{In vitro gas production}

Animal husbandry. The animal study was carried out according to the guidelines of Erciyes University Local Ethics Committee (Kayseri, Turkey). Faeces samples for the in vitro gas production technique were collected from 7 male, 6-month old, breeding rabbits (New Zealand White) obtained from the Experimental Research and Application Centre of Erciyes University (Kayseri, Turkey). The rabbits were housed individually and maintained in heatsterilized, wirefloored metal cages with a hard plastic litter box $(60 \mathrm{~cm} \times 60 \mathrm{~cm})$ at $18-23{ }^{\circ} \mathrm{C}$ ambient temperature. The rabbits were fed commercial laboratory rabbit diet (Optima Feed; Bolu, Turkey) with $17.0 \% \mathrm{CP}, 13.65 \% \mathrm{CF}$ (crude fibre) and $3.2 \% \mathrm{EE}$. Feed and water were available ad libitum.

In vitro fermentation experiment. The faeces were collected in the morning and $10 \mathrm{~min}$ later processed in the laboratory. The inoculum was prepared by pooling the fresh faeces. To $100 \mathrm{~g}$ of fresh faeces was added $400 \mathrm{ml}$ of anaerobic medium, then the mixture was stirred and strained through six layers of muslin. The remaining solids were resuspended in $400 \mathrm{ml}$ of medium and homogenized using a laboratory type blender (Waring; Torrington, CT, USA) for $20 \mathrm{~s}$. The homogenate was strained through six layers of muslin at $39^{\circ} \mathrm{C}$ under $\mathrm{CO}_{2}$ (final dilution 8:1 medium:faeces).

The inoculum fluid was prepared by mixing one part of the filtrate with six parts of the artificial saliva medium consisting of in vitro anaerobic buffer solution, macro- and micro-mineral solutions, resazurin and reduction solution, as described by Menke et al. (1979). Representative samples of dietary fibre feedstuffs were ground through a 1-mm screen. Each of the feedstuffs (about $500 \mathrm{mg} \mathrm{DM}$ ) was weighed into three syringes (Model Fortuna; Lonsee, Germany) and incubated with $35 \mathrm{ml}$ of the inoculum fluid at $39 \pm 0.2^{\circ} \mathrm{C}$ for $96 \mathrm{~h}$, as described by Menke et al. (1979) in a ruminant in vitro experiment. Gas production measurements $(\mathrm{ml})$ were taken after 3,6 , $12,24,48,72$ and $96 \mathrm{~h}$ of incubation and the results were corrected for the blank. Measurements were conducted in triplicate.

Calculation of gas production kinetics. $\mathrm{Cu}-$ mulative gas production data were fitted to the exponential equation of Ørskov and McDonald (1979) using a computer package programme called Fig $\mathrm{P}$ (Biosoft; Cambridge, UK):

$$
\mathrm{Y}=\mathrm{a}+\mathrm{b}\left(1-\exp ^{\mathrm{ct}}\right)
$$

where: $\mathrm{a}$-gas production from immediately soluble fraction (ml); $b$ - gas production from the insoluble fraction (ml); c - gas production rate constant; $\mathrm{a}+\mathrm{b}-$ potential gas production $(\mathrm{ml}) ; \mathrm{t}-$ incubation time (h); $y$ - gas produced at time $\mathrm{t}$.

\section{Statistical analysis}

At first the experimental data were subjected to Levene's test to detect the variance homogeneity. One-way variance analyses (ANOVA) were implemented for homogeneous variances by General Linear Model procedures to test treatment differences. Data were analysed on the basis of the statistical model:

$$
\mathrm{Y} i j=\mu i j+\mathrm{S} i+\mathrm{e} i
$$

where: Yij - general mean common for each parameter; $\mathrm{S} i$ - effect of dietary fibre feedstuffs; e $i$-standard error.

The means were separated by Tukey's multiple range test at $P<0.05$. The data were presented on the basis of mean \pm standard error of mean.

Linear relations between the dietary fibre and condensed tannin composition with gas production kinetics were determined as Pearson's correlation coefficients $(r)$. 
Analyses were performed using SPSS 17.0 software (IBM Corp.; Armonk, NY, USA).

\section{Results}

The ash content in the feedstuffs widely ranged from 3.2 to $11.1 \%$ (Table 1). The highest level of $\mathrm{CP}$ was in lucerne meal $(22.5 \%)$, whereas the lowest - in pomegranate peel $(8.4 \%)$. The EE content widely ranged from 0.3 to $17.1 \%$. The TDF and IDF contents of rice bran were the lowest, but were the highest in the sugar beet pulp (Table 2). The hemicellulose contents of sugar beet pulp, wheat bran and maize bran were $>25 \%$ DM. The highest digestible fibre fraction was determined in sugar beet pulp (44.5\%). The highest content of ADL was in pomegranate peel $(16.7 \%)$ and lentil bran $(10.1 \%)$, and the lowest - in sugar beet pulp (3.2\%). The TCT contents were estimated in a wide range from 0.16 to $9.67 \%$ in DM (Table 3). The highest TCT, BCT and ECT contents were found in lentil bran, however only in lentil bran the $\mathrm{BCT}$ value was greater than the ECT value.

Table 1. Composition of fibrous feedstuffs, $\%$ DM

\begin{tabular}{llrrrl}
\hline Feedstuffs & DM & \multicolumn{1}{c}{ Ash } & \multicolumn{1}{c}{ CP } & \multicolumn{1}{c}{ EE } & NSC \\
\hline Sugar beet pulp & 93.7 & 5.7 & 10.7 & 0.3 & 29.0 \\
Lucerne meal & 94.5 & 8.9 & 22.5 & 0.5 & 25.5 \\
Wheat bran & 93.5 & 5.6 & 17.7 & 2.9 & 33.2 \\
Tomato pomace & 90.7 & 11.1 & 13.7 & 0.9 & 55.2 \\
Maize bran & 90.9 & 6.0 & 16.0 & 1.6 & 37.2 \\
Rice bran & 91.5 & 8.3 & 18.8 & 17.1 & 32.2 \\
Lentil bran & 92.4 & 3.2 & 14.0 & 0.6 & 31.8 \\
Pomegranate peel & 96.6 & 4.3 & 8.4 & 0.4 & 55.4
\end{tabular}

$\mathrm{DM}$ - dry matter content as \% in feed; $\mathrm{CP}$ - crude protein; $\mathrm{EE}$ - diethyl ether extract; NSC - non-structural carbohydrates (100 - ash - EE - CP - aNDFom) (NRC, 2001); aNDFom - thermostable a-amylase treated neutral detergent fibre content corrected for ash as \% in DM

Table 2. Fibre composition of feedstuffs, \% DM

\begin{tabular}{lllllllllll}
\hline Feedstuffs & TDF & aNDFom & ADFom & IDF & SDF & Hemicellulose & ADL & \multicolumn{1}{c}{ SF } & WIP & DgF \\
\hline Sugar beet pulp & 70.2 & 54.3 & 25.7 & 63.1 & 7.1 & 28.6 & 3.2 & 15.9 & 8.8 & 44.5 \\
Lucerne meal & 53.9 & 42.6 & 32.9 & 48.2 & 5.7 & 9.7 & 7.0 & 11.3 & 5.6 & 21.0 \\
Wheat bran & 44.0 & 40.6 & 12.7 & 40.9 & 3.1 & 27.9 & 7.8 & 3.4 & 0.3 & 31.3 \\
Tomato pomace & 34.5 & 19.1 & 17.5 & 27.6 & 6.9 & 1.6 & 6.9 & 15.4 & 8.5 & 17.0 \\
Maize bran & 44.0 & 39.2 & 10.5 & 39.7 & 2.7 & 28.7 & 6.9 & 4.8 & 2.1 & 30.8 \\
Rice bran & 28.9 & 23.6 & 9.3 & 23.7 & 3.7 & 14.3 & 7.3 & 5.3 & 1.6 & 15.9 \\
Lentil bran & 67.1 & 50.4 & 38.8 & 59.2 & 7.9 & 11.6 & 10.1 & 16.7 & 8.8 & 28.3 \\
Pomegranate peel & 45.8 & 34.5 & 33.0 & 39.0 & 6.8 & 1.5 & 16.7 & 11.3 & 4.5 & 12.8 \\
\hline
\end{tabular}

TDF - total dietary fibre; aNDFom - see Table 1; ADFom - acid detergent fibre content corrected for ash; IDF - insoluble dietary fibre; SDF - soluble dietary fibre; hemicelluloses (aNDFom - ADFom); ADL - acid detergent lignin; SF - soluble fibre (TDF - aNDFom); WIP - waterin soluble pectins (SF - SDF); DgF - digestible fibre fractions (hemicelluloses + SF)
The gas production rate $\left(\mathrm{ml} \cdot \mathrm{h}^{-1}, 0.5 \mathrm{~g} \mathrm{DM}\right)$ of lentil bran was higher $(P<0.001)$ than those of the other dietary fibre sources (Table 4$)$. The in vitro gas production from insoluble fraction (111.2 and $\left.100.1 \mathrm{ml} \cdot 0.5 \mathrm{~g}^{-1} \mathrm{DM}\right)$ and potential gas production $\left(105.5\right.$ and $\left.94.7 \mathrm{ml} \cdot 0.5 \mathrm{~g}^{-1} \mathrm{DM}\right)$ values were the highest in tomato pomace and sugar beet pulp, respectively. The in vitro gas production form insoluble fraction and potential gas production of maize

Table 3. Condensed tannins composition of dietary fibre feedstuffs, $\%$ DM

\begin{tabular}{lcccc}
\hline Feedstuffs & TCT & BCT & ECT & ECT : BCT \\
\hline Sugar beet pulp & 0.16 & 0.06 & 0.10 & 1.54 \\
Lucerne meal & 0.61 & 0.25 & 0.36 & 1.44 \\
Wheat bran & 0.22 & 0.05 & 0.17 & 3.27 \\
Tomato pomace & 2.30 & 1.14 & 1.16 & 1.02 \\
Maize bran & 0.17 & 0.05 & 0.12 & 2.45 \\
Rice bran & 0.40 & 0.03 & 0.37 & 11.97 \\
Lentil bran & 9.67 & 5.11 & 4.56 & 0.89 \\
Pomegranate peel & 0.84 & 0.24 & 0.60 & 2.50
\end{tabular}

TCT - total condensed tannin; BCT - bound condensed tannin; ECT - extractable condensed tannin

Table 4. In vitro gas production kinetics of dietary fibre feedstuffs

\begin{tabular}{llrc}
\hline Feedstuffs & $c$ & $b$ & $a+b$ \\
\hline Sugar beet pulp & $0.0265^{\mathrm{bc}}$ & $100.05^{\mathrm{b}}$ & $94.72^{\mathrm{b}}$ \\
Lucerne meal & $0.0410^{\mathrm{bc}}$ & $40.76^{\mathrm{d}}$ & $38.61^{\mathrm{de}}$ \\
Wheat bran & $0.0340^{\mathrm{bc}}$ & $43.50^{\mathrm{d}}$ & $41.22^{\mathrm{d}}$ \\
Tomato pomace & $0.0145^{\mathrm{c}}$ & $111.20^{\mathrm{a}}$ & $105.51^{\mathrm{a}}$ \\
Maize bran & $0.0340^{\mathrm{bc}}$ & $64.96^{\mathrm{c}}$ & $60.64^{\mathrm{c}}$ \\
Rice bran & $0.0470^{\mathrm{b}}$ & $38.77^{\mathrm{d}}$ & $36.25^{\mathrm{e}}$ \\
Lentil bran & $0.0820^{\mathrm{a}}$ & $4.83^{\mathrm{f}}$ & $4.17^{\mathrm{a}}$ \\
Pomegranate peel & $0.0345^{\mathrm{bc}}$ & $16.72^{\mathrm{e}}$ & $15.40^{\mathrm{f}}$ \\
SEM & 0.004 & 9.04 & 8.60 \\
P-value & $<0.001$ & $<0.001$ & $<0.001$
\end{tabular}

$c$ - gas production rate $\left(\mathrm{ml} \cdot \mathrm{h}^{-1}, 0.5 \mathrm{~g} \mathrm{DM}\right) ; \mathrm{b}$ - gas production from insoluble fraction $\left(\mathrm{ml} \cdot 0.5 \mathrm{~g}^{-1} \mathrm{DM}\right) ;(\mathrm{a}+\mathrm{b})$ - potential gas production $\left(\mathrm{ml} \cdot 0.5 \mathrm{~g} \mathrm{~g}^{-1} \mathrm{DM}\right)$; SEM - standard error of mean; ${ }^{\mathrm{a}-\mathrm{g}}-$ means within columns with different superscripts are significantly different at $P \leq 0.05$ 
Table 5. Correlation coefficient ( $r$ ) relationship of dietary fibre and condensed tannin composition with gas production kinetics

\begin{tabular}{lllllllll}
\hline Indices & $\mathrm{b}$ & $\mathrm{a}+\mathrm{b}$ & TDF & IDF & SDF & TCT & $\mathrm{BCT}$ & $\mathrm{ECT}$ \\
\hline $\mathrm{c}$ & $-0.758^{* *}$ & $-0.757^{* *}$ & 0.469 & $0.654^{*}$ & -0.196 & $0.825^{* *}$ & $0.814^{* *}$ & $0.835^{* *}$ \\
$\mathrm{~b}$ & 1 & $0.990^{* *}$ & -0.304 & $-0.580^{*}$ & 0.487 & $-0.513^{*}$ & -0.487 & $-0.543^{*}$ \\
$\mathrm{a}+\mathrm{b}$ & & 1 & -0.304 & $-0.580^{*}$ & 0.488 & $-0.513^{*}$ & -0.486 & $-0.542^{*}$ \\
TDF & & 1 & $0.905^{* *}$ & $0.545^{*}$ & 0.420 & 0.428 & 0.410 \\
IDF & & & 1 & 0.146 & $0.560^{*}$ & $0.564^{*}$ & $0.555^{*}$ \\
SDF & & & & 1 & -0.031 & -0.016 & -0.048 \\
TCT & & & & & & 1 & $0.999^{* *}$ & $0.999^{* *}$ \\
BCT & & & & & & & 1 & $0.996^{* *}$
\end{tabular}

c, b, $(\mathrm{a}+\mathrm{b})$ - see Table 4; TDF, SDF, IDF - see Table 2; TCT, BCT, ECT - see Table 3; * correlation is significant at $P=0.01$; ** correlation is significant at $P=0.05$

Table 6. Pearson's correlation coefficient ( $r$ ) relationship of dietary fibre and condensed tannin composition with gas production kinetics

\begin{tabular}{llllllll}
\hline Indices & Pearson's correlation & $\mathrm{ADFom}^{2}$ & $\mathrm{ADL}^{2}$ & Hemicellulose $^{2}$ & $\mathrm{SF}^{2}$ & $\mathrm{WIP}^{2}$ & $\mathrm{DgF}^{2}$ \\
\hline $\mathrm{c}^{1}$ & $r$ & 0.462 & 0.242 & -0.046 & 0.129 & 0.089 & 0.005 \\
& $P$-value & 0.071 & 0.366 & 0.864 & 0.634 & 0.742 & 0.986 \\
$\mathrm{~b}^{1}$ & $r$ & -0.429 & $-0.671^{* *}$ & 0.208 & 0.195 & 0.296 & 0.335 \\
& $P$-value & 0.097 & 0.004 & 0.440 & 0.470 & 0.265 & 0.205 \\
$\mathrm{a}+\mathrm{b}^{1}$ & $r$ & -0.426 & $-0.670^{* *}$ & 0.205 & 0.198 & 0.299 & 0.334 \\
& $P$-value & 0.100 & 0.005 & 0.447 & 0.462 & 0.261 & 0.206 \\
\hline
\end{tabular}

${ }^{1}$ see Table $4 ;{ }^{2}$ see Table $2 ;{ }^{* *}$ correlation is significant at $P=0.01$

bran were higher $(P<0.001)$ than those of the other studied cereal brans (wheat and rice). The lowest potential gas production $\left(4.2 \mathrm{ml} \cdot 0.5 \mathrm{~g}^{-1} \mathrm{DM}\right)$ was determined in lentil bran. The in vitro gas production from insoluble fraction and potential gas production values were higher $(P<0.001)$ in pomegranate peel than those in lentil bran.

The correlation coefficient $(r)$ between dietary fibre and condensed tannin concentration with gas production kinetics is presented in Table 5. For different fibre feedstuffs, the $c_{\text {gas }}$ was negatively correlated with $\mathrm{b}_{\text {gas }}(r=-0.758 ; P<0.01)$ and $(\mathrm{a}+\mathrm{b})_{\text {gas }}(r=-0.757 ; P<0.01)$ and positively correlated with IDF $(r=0.654 ; P<0.05)$, TCT $(r=0.825 ; P<0.01)$, BCT $(r=0.814 ; P<0.01)$ and ECT $(r=0.835 ; P<0.01)$. The $\mathrm{b}_{\text {aas }}$ and $(\mathrm{a}+\mathrm{b})_{\text {aas }}$ were negatively correlated with IDF $(r=-0.580 ; P<0.05)$, TCT $(r=-0.513 ; P<0.05)$ and ECT $(r=-0.543$ and $r=-0.542 ; P<0.05)$. The TDF was positively correlated with IDF $(r=0.905$; $P<0.01)$ and SDF $(r=0.545 ; P<0.05)$. The TDF content of dietary fibre feedstuffs was positively correlated with TCT, BCT and ECT $(r=0.560$, $r=0.564$ and $r=0.555$, respectively; $P<0.05$ ).

Also, $\mathrm{b}_{\text {gas }}$ and $(\mathrm{a}+\mathrm{b})_{\text {gas }}$ were negatively correlated with the ADL $(r=-0.671$ and $r=-0.670 ; P<0.01)$ content of fibrous feedstuffs. The $\mathrm{c}_{\text {gas }}, \mathrm{b}_{\text {gas }}$ and $(\mathrm{a}+\mathrm{b})_{\text {gas }}$ values of fibrous feedstuffs were not correlated with the ADFom, SF, WIP and DgF contents of those feedstuffs $(P>0.05$; Table 6$)$.

\section{Discussion}

In the dietary fibre analysis method (Prosky et al., 1988) used in the study, residue includes the non-starch polysaccharides and lignins, the sum of resistant starch, inulin and non-carbohydrate (Institute of Medicine, 2001). So, examined feedstuffs may be classified according to their TDF concentration: high TDF content (TDF $\geq 600 \mathrm{~g} \cdot \mathrm{kg}^{-1}$; sugar beet pulp and lentil bran), moderate TDF content (TDF $\geq 400 \mathrm{~g} \cdot \mathrm{kg}^{-1}$; lucerne meal, pomegranate peel, wheat bran and maize bran) and low TDF content (TDF $\geq 200 \mathrm{~g} \cdot \mathrm{kg}^{-1}$; rice bran and tomato pomace).

Water-soluble non-starch polysaccharides consist partly of $\beta$-glucans and arabinoxylans, and pectic substances. The main characteristic of these compounds is represented by the capacity to bind water, forming a gelatinous mass (Gidenne, 2015). In the present study, sugar beet pulp included TDF, soluble fibre, hemicellulose, water-insoluble pectin and digestible fibre fractions at high levels. The TDF content of tomato pomace was low; otherwise, soluble fibre content was high. Fibre contents (TDF, IDF, SDF) of wheat bran, maize bran and pomegranate peel were very close and at moderate levels. Lucerne meal and lentil bran had high TDF levels. Rice bran and tomato pomace contained fibre substances. The TDF and aNDFom values were the lowest in tomato pomace and rice. The highest potential gas production and the gas production from insoluble 
fraction values were found in tomato pomace, which could be related to low TDF and aNDFom contents and high SDF ratio (35.2\% in TDF). In the study of Peiretti et al. (2012) it was stated that tomato pomace may be satisfactorily used as a dietary feedstuff for rabbits at levels of up to $6 \%$ in the diet without any adverse effect on the performance or nutritive value. In addition, the high potential gas production and the gas production from insoluble fraction (second highest) values of sugar beet pulp could be associated with low TCT and high SDF contents. An important component of SDF is pectin. Kermauner and Lavrencic (2010) stated that the potential gas production of different commercially available pectin sources (beet, apple and citrus pulp) were determined in rabbit as $144-188 \mathrm{ml} \cdot 0.5 \mathrm{~g}^{-1} \mathrm{DM}$. In the present study, tomato pomace and sugar beet pulp, in particular, increased in vitro gas production by substrate, thus indicating an increased microbial fermentation intensity. This positive effect may be related to the high contents of soluble fibre and water-insoluble pectin and low of lignin and condensed tannins. Water-insoluble pectins and water soluble fibres are rapidly fermentable dietary fibres. In addition, this high gas production may be associated with the presence of hemicellulose and DgF in sugar beet pulp and NSC in tomato pomace.

Most concentrate feeds and young forages contain less than 5\% ADL. The degree of plant cell wall lignification may reach $12 \%$ with forage ageing (Gidenne, 2015). In the present study, lentil bran and pomegranate peel contained more than 10\% ADL. The lowest ADL and the highest fermentation level were in sugar beet pulp. Other fibrous feedstuffs had about $7 \%$ ADL.

The in vitro gas production values of lucerne meal, wheat and maize brans may be connected with their aNDFom content ranging from 41.82 to $42.6 \%$. Similar results were obtained by Miśta et al. (2015) who found that the in vitro gas production of wheat bran in rabbit equalled $37.9 \mathrm{ml} \cdot 0.5 \mathrm{~g}^{-1}(90.96 / 1.2 \mathrm{~g})$. Whereas Bovera et al. (2006) estimated in rabbits the potential gas production at $86 \mathrm{ml} \cdot 0.5 \mathrm{~g}^{-1}$ and $155 \mathrm{ml} \cdot 0.5 \mathrm{~g}^{-1}$ for dehydrated lucerne meal and beet pulp, respectively. The difference between our and Bovera et al. (2006) study may be due to the result of different age of animals, diets, condensed tannin content of the consumed diet and other environmental factors.

Although rice bran had low fibre (aNDFom, TDF and SDF) and low NSC and TCT contents, this agro-crop had moderate effect on the potential gas production. The potential gas production of rice bran was lower than those of other agro-crops (maize and wheat brans) and this may be related to the low digestible fibre fractions (hemicelluloses + soluble fibre) content. The gas production from insoluble fraction of rice bran was similar to those of wheat bran and lucerne meal. The water-insoluble pectin (WIP) content in rice bran was lower (about $80 \%$ ratio) than in sugar beet pulp and tomato pomace, which had a high WIP content. In addition, the low potential gas production of rice bran may be associated with EE content (17.11\%). Rice bran oil contains high level of unsaturated fatty acid (Oluremi et al., 2013) which in animal diets can decrease the digestibility of fibre substances (Jenkins, 1993).

The low values of gas production from insoluble fraction and potential gas production in lentil bran may be related to the high level $\left(96.7 \mathrm{~g} \cdot \mathrm{kg}^{-1}\right)$ of TCT (both BCT and ECT) and IDF (59.2\%). Both BCT and ECT of rice bran were determined to have the highest values: 51.1 and $45.6 \mathrm{~g} \cdot \mathrm{kg}^{-1} \mathrm{DM}$, respectively. Bound condensed tannins occur in combination with protein or/and fibre components (Mueller-Harvey, 2001). The TDF contents of dietary fibre feedstuffs in the current study were positively correlated with TCT, BCT and ECT.

CT have both positive (low levels of CT: $<3 \%$ ) and negative (high levels of CT: $>5 \%$ ) effects on feed digestibility and animal performance, depending both on the quantity and biological activity of the condensed tannins (Schofield et al., 2001; Min et al., 2006; Kara et al., 2015). The multiple phenolic hydroxyl groups of condensed tannins (or proanthocyanidins) lead to the formation of complexes with proteins, metal ions and other macromolecules like polysaccharides (Schofield et al., 2001). Condensed tannins, especially ECT, bind with macro molecules. In our previous study (Kara et al., 2015) it was stated that in vitro total gas production was negatively correlated with condensed tannins. Lentil bran had high condensed tannin content $(9.7,5.1$ and $4.6 \%$ DM for TCT, BCT and ECT, respectively) and high fibre content (67.1 and $59.2 \%$ DM for TDF and IDF, respectively), however it has low gas production values. In this experiment, the TCT, BCT and ECT values were negatively correlated with the gas production from insoluble fraction (b) and potential gas production $(a+b)$ values.

\section{Conclusions}

Tomato pomace, maize bran and rice bran could be recommended for use as alternative dietary fibre feedstuffs for post-weaning, young and breeding rabbits. Although tomato pomace has excessive 
fermentation capacity, the dietary fibre content of it was low. On the other hand, the use of pomegranate pomace and lentil bran as a good source of low digested fibre can be recommended for the growing rabbit due to their high fibre content and low fermentation capacity. Moreover, the effects of dietary fibrous feedstuffs on different metabolic parameters (organic acid profile and microbial population in digest fluid, faeces quality etc.) need to be investigated in the future in in vitro and in vivo studies conducted on rabbits.

\section{References}

Alvarez J.L., Marguenda I., García-Rebollar P., Carabaño R., De Blas C., Corujo A., García-Ruiz A.l., 2007. Effects of type and level of fibre on digestive physiology and performance in reproducing and growing rabbits. World Rabbit Sci. 15, 9 -17

AOAC International, 2012. Official Methods of Analysis of AOAC International. 19th Edition. Gaithersburg, MD (USA)

Bovera F., D’Urso S., Di Meo C., Piccolo G., Calabró S., Nizza A., 2006. Comparison of rabbit caecal content and rabbit hard faeces as source of inoculum for the in vitro gas production technique. Asian-Austral. J. Anim. Sci. 19, 1649-1657

Bovera F., Marono S., Di Meo C., Piccolo G., lannaccone F., Nizza A., 2010. Effect of mannanoligosaccharides supplementation on caecal microbial activity of rabbits. Animal 4, 1522-1527

Elghandour M.M.Y., Kholif A.E., López S., Mendoza G.D., Odongo N.E., Salem A.Z.M., 2016. In vitro gas, methane, and carbon dioxide productions of high fibrous diet incubated with fecal inocula from horses in response to the supplementation with different live yeast additives. J. Equine Vet. Sci. 38, 64-71

Gidenne T., 2003. Fibres in rabbit feeding for digestive troubles prevention: respective role of low-digested and digestible fibre. Livest. Prod. Sci. 81,105-117

Gidenne T., 2015. Dietary fibres in the nutrition of the growing rabbit and recommendations to preserve digestive health: a review. Animal 9, 227-242

Gidenne T., Carabaño R., García J., de Blas C., 2010. Fibre digestion. In: C. de Blas, J. Wiseman (Editors). Nutrition of the Rabbit. $2^{\text {nd }}$ Edition. CAB International. London (UK), pp. 66-82

Guo F.C., Williams B.A., Kwakkel R.P., Verstegen M.W.A., 2003. In vitro fermentation characteristics of two mushroom species, an herb, and their polysaccharide fractions, using chicken cecal contents as inoculum. Poultry Sci. 82,1608-1615

Institute of Medicine, 2001. Dietary Reference Intakes: Proposed Definition of Dietary Fibre. The National Academies Press. Washington DC (USA), doi:10.17226/10161

Jenkins T.C., 1993. Lipid metabolism in the rumen. J. Dairy Sci. 76, 3851-3863

Kara K., 2015. In vitro methane production and quality of corn silage treated with maleic acid. Ital. J. Anim. Sci. 14, 718-722
Kara K., Güçlü B.K., Baytok E., 2015. Comparison of nutrient composition and anti-methanogenic properties of different Rosaceae species. J. Anim. Feed Sci. 24, 308-314

Kermauner A., Lavrencic A., 2010. In vitro fermentation of different commercially available pectins using inoculum from rabbit caecum. World Rabbit Sci. 18, 1-7

Makkar H.P.S., Blümmel M., Becker K., 1995. Formation of complexes between polyvinyl pyrrolidones or polyethylene glycols, and their implication in gas production and true digestibility in in vitro techniques. Brit. J. Nutr. 73, 897-913

Menke K.H., Raab L., Salewski A., Steingass H., Fritz D., Schneider W., 1979. The estimation of digestibility and metabolizable energy content of ruminant feedingstuffs from the gas production when they are incubated with rumen liquor in vitro. J. Agr. Sci. 93, 217-222

Miltko R., Kowalik B., Majewska M., Bełżecki G., Skomiał J., 2015. The influence of supplementing heifer diets with Saccharomyces cerevisiae yeast on the activity of polysaccharidases in the rumen. J. Anim. Feed Sci. 24, 260-264

Min B.R., Pinchak W.E., Anderson R.C., Fulford J.D., Puchala R., 2006. Effects of condensed tannins supplementation level on weight gain and in vitro and in vivo bloat precursors in steers grazing winter wheat. J. Anim. Sci. 84, 2546-2554

Miśta D., Króliczewska B., Marounek M., Pecka E., Zawadzki W., Nicpoń J., 2015. In vitro study and comparison of caecal methanogenesis and fermentation pattern in the brown hare (Lepus europaeus) and domestic rabbit (Oryctolagus cuniculus). PLoS ONE 10, e0117117, doi:10.1371/journal. pone. 0117117

Mueller-Harvey I., 2001. Analysis of hydrolysable tannins. Anim. Feed Sci. Tech. 91, 3-20

NRC, 2001. Nutrient Requirements of Dairy Cattle. $7^{\text {th }}$ revised Edition. National Academy Press. Washington, DC (USA)

Oluremi O.I., Solomon A.O., Saheed A.A., 2013. Fatty acids, metal composition and physico-chemical parameters of Igbemo Ekiti rice bran oil. J. Environ. Chem. Ecotoxicol. 5, 39-46

Ørskov E.R., McDonald I., 1979. The estimation of protein degradability in the rumen from incubation measurements weighted according to rate of passage. J. Agr. Sci. 92, 499-503

Peiretti P.G., Gai F., Rotolo L., Gasco L., 2012. Effects of diets with increasing levels of dried tomato pomace on the performances and apparent digestibility of growing rabbits. Asian J. Anim. Vet. Adv. 7, 521-527

Prosky L., Asp N.G., Schweizer T.F., DeVries J.W., Furda I., 1988. Determination of insoluble, soluble, and total dietary fiber in foods, food products: interlaboratory study. J. Assoc. Off. Anal. Chem.71, 1017-1023

Schofield P., Mbugua D.M., Pell A.N., 2001. Analysis of condensed tannins: a review. Anim. Feed Sci. Tech. 91, 21-40

Van Soest P.J., Robertson J.B., Lewis B.A., 1991. Methods for dietary fiber, neutral detergent fiber and non starch polysaccharides in relation to animal nutrition. J. Dairy Sci. 74, 3583-3597 